\title{
NIEZGODNOŚĆ FORM PRZEZNACZENIA TERENÓW W PLANOWANIU PRZESTRZENNYM - METODA IDENTYFIKACJI POTENCJALNYCH KONFLIKTÓW PRZESTRZENNO-FUNKCJONALNYCH ${ }^{1}$
}

Zarys treści Przedmiotem artykułu są potencjalne konflikty, rozumiane jako zespół zjawisk rozpatrywanych w kontekście przestrzenno-funkcjonalnym, które są wynikiem prowadzonej polityki przestrzennej na poziomie lokalnym. Głównym celem przeprowadzonych badań była identyfikacja najważniejszych potencjalnych konfliktów przestrzenno-funkcjonalnych na obszarze Wrocławskiego Obszaru Metropolitalnego. W pracy zaproponowano metodologię, która umożliwia zautomatyzowanie postępowania badawczego. Pozwoli to włączyć identyfikację konfliktów przestrzenno-funkcjonalnych do działań decyzyjnych w zakresie planowania przestrzennego jako element towarzyszący i uzupełniający.

Słowa kluczowe Konflikty przestrzenno-funkcjonalne, planowanie przestrzenne na poziomie lokalnym, obszar metropolitalny.

\section{Wprowadzenie}

Od kilkunastu lat obserwuje się w Polsce silną ekspansję przestrzenną miast na tereny wiejskie. W szczególności dotyczy to strefy podmiejskiej: pojawia się $\mathrm{w}$ niej rozwinięte budownictwo mieszkaniowe, usługowe i produkcyjne oraz obserwuje się napływ ludności z miast. Zmienia się struktura użytkowania ziemi, a także pełnione funkcje społeczno-gospodarcze (Gonda-Soroczyńska 2009). Potrzeba rozwoju ekonomicznego, powiązana z rozbudową trwałej infrastruktury i zmianą użytkowania terenów, prowadzi do powstawania konfliktów w zakresie planowania funkcji danego terytorium. Koszty ekologiczne, społeczne, a także ekonomiczne konfliktów nie rozwiązanych w fazie planowania, zwykle gwałtownie rosną na etapie realizacji określonych projektów (Kołodziejski 1988).

\footnotetext{
${ }^{1}$ Artykuł powstał na podstawie pracy doktorskiej Anny Grochowskiej (2016).
} 
Przedmiotem artykułu są potencjalne konflikty, rozumiane jako zespół zjawisk rozpatrywanych w kontekście przestrzenno-funkcjonalnym, które są wynikiem prowadzonej na poziomie lokalnym polityki przestrzennej. W niniejszej pracy wykorzystywane jest pojęcie konfliktu przestrzennego, definiowane za J. Ulańską i M. Borowską-Stefańską (2012), jako niezgodność w przeznaczeniu sąsiadujących terenów, wiążącą się z oddziaływaniem negatywnych efektów zewnętrznych (degradacja elementów przyrody ożywionej i nieożywionej, uciążliwość dla okolicznych mieszkańców) i skutkującą obniżoną efektywnością ich funkcjonowania.

Ustawa z dnia 27 marca 2003 roku o planowaniu i zagospodarowaniu przestrzennym nadaje jednostce administracyjnej, jaką jest gmina, wiele kompetencji władczych z zakresu planowania przestrzennego (Dz.U. 2003, nr 80, poz. 717). Na poziomie lokalnym rozstrzygają się najważniejsze decyzje związane z zagospodarowaniem i użytkowaniem terenu. Stąd też właśnie gmina jest najbardziej zagrożona występowaniem konfliktów związanych z przestrzenią. W szczególności miejscem potencjalnego występowania sytuacji konfliktowych są granice administracyjne poszczególnych gmin. Takie założenie wynika z obowiązku określenia przez władze gminne kierunków polityki przestrzennej na swoim terytorium i braku nakazu uwzględniania sytuacji panującej na obszarach sąsiadujących jednostek administracyjnych ${ }^{2}$.

Głównym celem poznawczym przeprowadzonych badań była identyfikacja najważniejszych potencjalnych konfliktów przestrzennych na obszarze Wrocławskiego Obszaru Metropolitalnego (zwanego dalej WrOM). Jednostką odniesienia terytorialnego dla analiz była gmina.

Celem metodologicznym było opracowanie metody identyfikacji potencjalnych konfliktów przestrzennych. Realizując to zadanie oparto się na postępowaniu badawczym opisanym przez J. Ulańską i M. Borowską-Stefańską (2012) w pracy poświęconej polityce przestrzennej w Lódzkim Obszarze Metropolitalnym, które zmodyfikowano do potrzeb niniejszej pracy.

Materiał źródłowy w postaci studiów uwarunkowań i kierunków zagospodarowania przestrzennego został przeanalizowany według stanu na 2016 rok.

Zakres przestrzenny badań objął WrOM, rozumiany jako teren, na którym realizowane będą przedsięwzięcia finansowane z budżetu Strategii Zintegrowanych Inwestycji Terytorialnych Wrocławskiego Obszaru Funkcjonalnego (zwanej dalej Strategią ZIT WrOF), w którego skład weszły: gmina Wrocław, miasto i gm. Jelcz-Laskowice, miasto i gm. Kąty Wrocławskie, gm. Siechnice, gm. Trzebnica, miasto i gm. Oborniki Śląskie, miasto i gm. Sobótka, miasto Oleśnica, gm. Oleśnica, gm. Długołęka, gm. Czernica, gm. Żórawina, gm. Kobierzyce, gm. Miękinia, gm. Wisznia Mała (ryc. 1).

${ }^{2}$ Założenie to było punktem wyjścia zaproponowanej przez J. Ulańską i M. Borowską-Stefańską metodologii badania konfliktów przestrzenno-funkcjonalnych w obszarach metropolitalnych (por. Ulańska, Borowska-Stefańska 2012). 


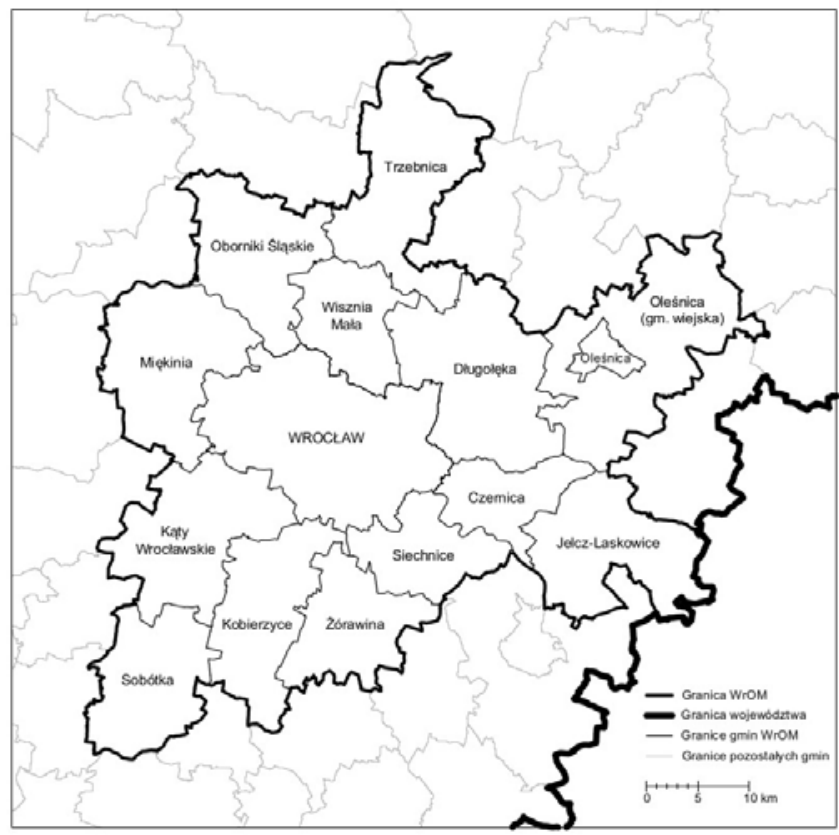

Ryc. 1. Obszar badań przyjęty w pracy - stan w 2016 roku Źródło: opracowanie własne na podstawie Strategii ZIT WrOF

\section{Wybrane problemy teoretyczne i badawcze. Pojęcie konfliktu przestrzennego}

Konflikty przestrzenne dotyczą wielu sfer życia społecznego. Można wyróżnić aspekty przestrzenne, przyrodnicze, ekonomiczne, kulturowe, społeczne, psychologiczne, polityczne, prawne, organizacyjne i techniczne (Dutkowski 1996; Schelzig 2005). B. Malisz (1984: 101) zauważa, że „konfliktów może być tyle, ile interakcji (na tle użytkowania przestrzeni) między różnego rodzaju podmiotami gospodarczymi, a mogą być tak rozmaite jak szeroka jest skala potrzeb społecznych i przestrzennych". Złożoność zjawiska oraz mnogość i rozmaitość konfliktów utrudnia ich jednoznaczne zdefiniowanie oraz klasyfikację. Funkcje terenów uznane jako niezgodne mogą stać się sytuacjami konfliktowymi, ale nie muszą. Natomiast zgodności w przeznaczeniu terenów nie są jednoznaczne z brakiem i niemożnością zaistnienia konfliktów. Mogą zajść takie okoliczności, że funkcje wydawałoby się całkowicie zgodne, wejdą ze sobą w konflikt.

Wielopłaszczyznowość zagadnienia sprawiła, że konflikty przestrzenne znalazły się w centrum zainteresowania różnych dziedzin nauki (Aspinall 2006). Do tradycyjnie badających je geografii i urbanistyki, dołączyły nauki społeczne, takie jak socjologia, ekonomia oraz prawo i administracja (Dutkowski 1996). Każda z wyżej wymienionych dyscyplin naukowych do zakresu swojej działalności 
badawczej włączyła identyfikację i rozwiązywanie konfliktów przestrzennych. M. Dutkowski (1996) stwierdza, że dla żadnej z nich jednak konflikty przestrzenne nie stanowią zagadnień centralnych i żadna nie jest kompetentna do ich pełnego badania i objaśniania. Co więcej, każdy autor w ramach swojej dziedziny inaczej ujmuje to zagadnienie. Takie subiektywne podejście powoduje brak jednolitych teoretycznych i metodycznych podstaw badania konfliktów przestrzennych, a nawet prowadzi do występowania sprzecznych definicji konfliktu (por. Bański 1999).

W jednej z pierwszych publikacji o obszarach konfliktowych J. Grocholska (1979: 84) zaprezentowała pogląd, że „obszary konfliktowe to takie, które cechuje duża intensywność występowania różnych przeciwstawnych funkcji lub obszary, na których rozwój jednej funkcji wiodącej osiągnął poziom zagrażający otaczającemu środowisku". W ujęciu J. Bańskiego (1998), źródłem konfliktu jest możliwość pełnienia przez wybrany obszar dwóch lub więcej funkcji i związana z tym konkurencja pomiędzy podmiotami gospodarczymi.

Pojęcie tak postrzeganego konfliktu przestrzennego ściśle związane jest z przestrzenią geograficzną, ponieważ to ona odgrywa w nim główną rolę. M. Dutkowski (1996) zaproponował termin „kolizja funkcji” dla oznaczenia niezgodności planowanych, tzn. przyszłych sposobów zagospodarowania przestrzennego. Geografowie i urbaniści najczęściej utożsamiają konflikt przestrzenny i funkcjonalno-przestrzenny właśnie z kolizyjnością funkcji (por. Grocholska 1979, 1980, 1983, 1986; Lendzion 1987; Zatorska-Sadurska 1990; Domański 1991; Śleszyński 2004). Niektórzy badacze żądają rozróżnienia pojęć konflikt przestrzenny i kolizja funkcji, argumentując, że sprzeczne funkcje mogą być źródłem konfliktu, ale niekoniecznie muszą. Konflikt jest natomiast uznawany za sytuację realnie już występującą między ludźmi, grupami społecznymi oraz między władzą publiczną a ludźmi itd. (Markowski 1999).

Część badaczy definicję konfliktu oparło na sprzeczności celów podmiotów gospodarczych i ograniczoności przestrzeni (m.in. Deutsch 1973; Kołodziejski 1982a, 1982b, 1988, 1991; Fraser, Hipel 1984; Malisz 1984; Zuziak 1995; Furmankiewicz, Potocki 2004; Jones i in. 2005). J. Kołodziejski (1982a, 1982b, 1988, 1991) zwrócił uwagę, że w procesie rozwoju wraz ze wzrostem jego wielowarstwowej złożoności, pojawiają się coraz częściej i z coraz większą ostrością konflikty między podmiotami gospodarującymi w przestrzeni i przestrzenią. Treścią konfliktów przestrzennych jest walka o dostęp do przestrzeni, do jej walorów i zasobów, prowadzona przez strony reprezentujące i realizujące różne, sprzeczne cele społeczne i gospodarcze. Źródłem sytuacji konfliktowej jest niedostateczna podaż przestrzeni o określonych cechach $\mathrm{w}$ stosunku do popytu na tę przestrzeń, wynikającego z konieczności zaspokajania określonych potrzeb społecznych w określonych sytuacjach przestrzennych lub konkurencja wartości, których nośnikiem jest przestrzeń. 
W definicjach wyżej wymienionych autorów, przedmiotem konfliktu jest sposób użytkowania przestrzeni, natomiast podmiotami członkowie społeczeństwa. Wcześniej zwracano przede wszystkim uwagę na aspekt przestrzenny problemu, następnie główny nacisk położono na element społeczny. Kolizja funkcji nie jest już wystarczającym powodem powstania konfliktu. Musi znaleźć się podmiot społeczny (osoba, grupa), który ujawni powstanie degradacji i stwierdzi, że jest ona sprzeczna z jego interesami lub poglądami (Kistowski 2008).

$\mathrm{Na}$ podstawie przytoczonych definicji i klasyfikacji wydaje się, że granica między konfliktami przestrzennymi a społecznymi jest coraz trudniejsza do uchwycenia. T. Markowski (1999: 169) zalicza konflikty przestrzenne do konfliktów społecznych, niemniej jednak podkreśla, że „konflikt społeczny o podłożu przestrzennym tym różni się od innych konfliktów społecznych, że właśnie u jego podłoża leży sposób użytkowania przestrzeni przez człowieka i związane z jego działalnością efekty zewnętrzne”. Za K. Dmochowską-Dudek (2011) można przyjąć, że konflikt jest rodzajem relacji (niezgodność, sprzeczność, wrogość), jaka zachodzi pomiędzy co najmniej dwoma podmiotami. Istota konfliktu jest taka sama w ujęciu społecznym i przestrzennym, różni się natomiast obszarem badań. W konflikcie społecznym przedmiotem badań są mechanizmy społeczne, a w konflikcie przestrzennym - przestrzeń. Konflikt przestrzenny jest rodzajem relacji, w której przedmiotem konfliktu jest sposób użytkowania przestrzeni, a jego podmiotem użytkownicy tej przestrzeni. W obydwu przypadkach zaznacza się jednak zawsze różnica w celach, dążeniach podmiotów konfliktu.

Na trudność identyfikacji konfliktów przestrzennych zwrócił również uwagę B. Malisz (1984), który zauważył, że wiele z sytuacji konfliktowych nie ma charakteru konfliktu w ściślejszym rozumieniu tego słowa. Są to na ogół straty spowodowane w otoczeniu bądź w całej gospodarce narodowej, wynikające z nieprzestrzegania przepisów prawa, bądź z niedbalstwa.

W niniejszej pracy wykorzystywane jest pojęcie konfliktu przestrzennego rozumianego jako niezgodność w przeznaczeniu sąsiadujących terenów, wiążąca się $\mathrm{z}$ oddziaływaniem negatywnych efektów zewnętrznych (degradacja elementów przyrody ożywionej i nieożywionej, uciążliwość dla okolicznych mieszkańców) i skutkująca obniżoną efektywnością ich funkcjonowania (Ulańska, Borowska-Stefańska 2012). Konflikt w ujęciu przestrzenno-funkcjonalnym, nawiązujący do tradycji badań geograficznych, którego istotą jest niezgodność funkcji, najlepiej zobrazuje problemy naukowe będące w centrum zainteresowania autorki artykułu. Różnorodność form sytuacji konfliktowych, uzależnionych od lokalnej specyfiki społeczno-gospodarczej i przyrodniczej jest tak duża, że włączanie do rozważań elementu społecznego, rozumianego jako identyfikacja uczestników sporu, byłoby dodatkowym, zbędnym elementem analizy. Wielokrotnie nie budzi wątpliwości istnienie konfliktu przestrzennego, natomiast wskazanie stron biorących w nim udział jest utrudnione albo wręcz niemożliwe. 


\section{Metodologia badań konfliktów przestrzennych}

Tematyka, zakres i charakter badań geograficznych, na użytek planowania przestrzennego, ulegały wielu przemianom ze względu na zainteresowania oraz możliwości ich wykonywania przez badaczy i geograficzne placówki naukowe (Dziewoński 1974; Malisz 1977). J. Grocholska $(1979,1980)$ zwróciła uwagę na brak metod analizy problematyki obszarów konfliktowych, które byłyby powszechnie stosowane w biurach planowania i zaproponowała teoretyczny schemat postępowania podczas opracowywania problematyki obszarów konfliktowych.

Instytut Geografii i Przestrzennego Zagospodarowania PAN realizuje opracowania dotyczące stanu i uwarunkowań prac planistycznych w gminach. Bazują one na danych z badań statystycznych statystyki publicznej GUS. Analiza danych odnośnie zaawansowania prac planistycznych uzupełniana jest dodatkowym badaniem ankietowym realizowanym w urzędach gminnych i powiatowych.

Jedną z częściej podejmowanych metod badawczych konfliktów przestrzennych oraz obszarów konfliktowych jest analiza aktualnych dokumentów przyjętych przez gminy i określających ich politykę przestrzenną. Dokumentację pierwotną stanowią wtedy studia uwarunkowań i kierunków zagospodarowania przestrzennego oraz plany miejscowe (w tym protesty i zarzuty do projektów planów), rzadziej decyzje lokalizacyjne i o pozwoleniu na budowę (por. Źróbek, Zachaś 2003; Krajewska 2004; Gołąb-Korzeniowska 2008; Hełdak 2012).

Najliczniejsza grupa opracowań dotyczących identyfikacji konfliktów przestrzennych opiera się na analizie zmiany w użytkowaniu ziemi na podstawie historycznych i aktualnych danych $\mathrm{z}$ ewidencji gruntów i budynków. $\mathrm{Z}$ reguły badania mają charakter studiów przypadków i dotyczą najczęściej konfliktów powstających na sąsiadujących obszarach (por. Furmankiewicz i Potocki 2004; Gołąb-Korzeniowska 2008; Tokajuk 2011; Hełdak 2012; Jabłoński, Mazurkiewicz 2014; Grochowska 2014, 2015).

Instytut Rozwoju Terytorialnego (IRT), w ramach prac nad projektem pn. „Studium spójności funkcjonalnej we Wrocławskim Obszarze Funkcjonalnym”, przeprowadził postępowanie badawcze obejmujące analizę polityk przestrzennych gmin, analizę wybranych planów miejscowych oraz konsultacje społeczne $\mathrm{z}$ przedstawicielami gmin zorganizowane $\mathrm{w}$ ramach projektu.

\section{Analiza niezgodności form przeznaczenia terenów - identyfikacja potencjalnych konfliktów przestrzenno-funkcjonalnych}

Głównym celem poznawczym badań była identyfikacja najważniejszych potencjalnych konfliktów przestrzenno-funkcjonalnych na obszarze WrOM. Jest to zadanie trudne $\mathrm{z}$ wielu względów, w tym braku ujednoliconych metod identyfikacji i analizy sytuacji konfliktowych. Po przeanalizowaniu na potrzeby pracy 
różnych postępowań badawczych, zdecydowano się zweryfikować metodę zaproponowaną przez J. Ulańską i M. Borowską-Stefańską (2012). Metoda oparta jest na analizach obejmujących tereny wzdłuż granic gmin (czyli analiza w makro-, a nie mikroskali pojedynczych działek), nie wymaga trudnych (czy wręcz niemożliwych) do uzyskania od władz samorządowych materiałów oraz charakteryzuje się większym obiektywizmem niż studia przypadków. Podczas próby implementacji metody na obszar WrOM, dokonano kilku zmian w metodologii. Spowodowane to było przede wszystkim potrzebą „zautomatyzowania” działań mających na celu identyfikację konfliktów przestrzenno-funkcjonalnych, co miałoby umożliwić obiektywne i porównywalne analizy dla rozległych powierzchniowo obszarów.

Punktem wyjścia w postępowaniach badawczych było przyjęcie założenia, że miejscem potencjalnego występowania konfliktów przestrzennych są granice poszczególnych gmin. Założenie to wynika z władztwa planistycznego gminy, czyli przekazania przez ustawodawcę samorządom terytorialnym kompetencji w zakresie władczego przeznaczania i zasad zagospodarowania terenu. Ustawa przewiduje istnienie dwóch dokumentów, na podstawie których gmina prowadzi politykę i gospodarkę przestrzenną. Są to: studium uwarunkowań i kierunków zagospodarowania przestrzennego gminy oraz miejscowy plan zagospodarowania przestrzennego.

Studium jest podstawowym dokumentem kreującym politykę przestrzenną gminy i wykonywane dla całego jej obszaru. Jego opracowanie i uchwalenie jest obowiązkowe. Studium nie stanowi jednak aktu prawa miejscowego, a więc nie zawiera przepisów powszechnie obowiązujących i nie może być podstawą do wydania decyzji administracyjnych. Jego ustalenia są wiążące dla jednostek samorządu terytorialnego przy sporządzaniu planów miejscowych. Gmina nie może decydować o przeznaczeniu i zasadach zagospodarowania terenu położonego poza jej granicami administracyjnymi. Nie ma również obowiązku dostosowywania kierunków zagospodarowania przestrzennego w studium do przeznaczeń terenów w jednostkach sąsiednich (Niewiadomski 2006). Stąd za wyjątkowo konfliktogenne uważa się „styki” granic administracyjnych gmin, gdzie następuje bezpośrednie zetknięcie prowadzonych przez samorządy terytorialne polityk przestrzennych.

Pierwszym etapem pracy nad identyfikacją konfliktów przestrzenno-funkcjonalnych było zgromadzenie dokumentów ksztaltujących politykę przestrzenną na terenie obszaru metropolitalnego Wrocławia. Podstawowym materiałem badawczym były studia uwarunkowań i kierunków zagospodarowania przestrzennego.

Kolejnym etapem analizy była identyfikacja docelowych form przeznaczenia terenu wzdłuż wszystkich granic gmin występujących w obrębie obszaru metropolitalnego. Studia zestawiane były parami, a następnie sprawdzano jakie przeznaczenia odpowiadają terenom po obu stronach granicy gmin. Zasięg 
analizy był uzależniony od rodzaju i powierzchni danego terenu. Przeważającą większość obszarów stanowiły formy wielko przestrzenne, obejmujące duże działki geodezyjne lub zespoły mniejszych jednostek ewidencyjnych. Jeżeli natomiast była to forma mała powierzchniowo (np. pojedyncza działka przeznaczona pod obiekt infrastruktury technicznej) lub o charakterze liniowym (np. droga, ciek wodny), w takim przypadku do analizy brana była pod uwagę kolejna, sąsiadująca $\mathrm{z}$ nią strefa.

Zebrane rysunki oraz części tekstowe studiów, stanowiące źródło danych dla badań, różnią się od siebie stopniem szczegółowości ustaleń, sposobem zapisu oraz oznaczeniami planistycznymi. Taka różnorodność związana jest przede wszystkim z brakiem wytycznych dotyczących stosowania nazewnictwa, oznaczeń i standardów przy sporządzaniu rysunku studium. Stąd każdy projektant przyjmuje własne, indywidualne rozwiązania dotyczące formy zapisu planistycznego.

Większość gmin z obszaru opracowania, za podstawę przyjęła podstawowe barwne oznaczenia graficzne i literowe dotyczące przeznaczenia terenów, zawarte w Rozporzadzeniu Ministra Infrastruktury z dnia 26 sierpnia 2003 roku w sprawie wymaganego zakresu projektu miejscowego planu zagospodarowania przestrzennego. Oznaczenia te były modyfikowane na potrzeby studiów, jednak na podstawie przyjętych kolorów, skrótów literowych oraz nazewnictwa funkcji terenów można było określić kierunki zagospodarowania przestrzennego bez wglądu do tekstu dokumentu. Wyjątek stanowił Wrocław, który w swoim studium wprowadził typy zespołów urbanistycznych, niemożliwe do rozszyfrowania bez zapoznania się z ich szczegółowymi opisami zawartymi w dokumencie. Ponadto ustalenia przyjęte przez Wrocław obejmowały wiele funkcji w ramach jednego przeznaczenia.

Różnorodność zapisów studiów sprawiła, że najtrudniejszym zadaniem na tym etapie pracy, było porównanie stref funkcjonalnych na „stykach” gmin. W celu zbadania spójności kierunków polityki przestrzennej samorządów terytorialnych, porównań i analiz dokonano generalizacji oraz ujednolicenia zapisów dotyczących przeznaczenia terenów. Oznaczenia literowe i nazewnictwo funkcji terenów ze studiów sprowadzono do nomenklatury zastosowanej w Rozporządzeniu Ministra Infrastruktury z dnia 26 sierpnia 2003 roku w sprawie wymaganego zakresu projektu miejscowego planu zagospodarowania przestrzennego. Zabieg ten różni metodologię niniejszej pracy od postępowania badawczego przeprowadzonego przez J. Ulańską i M. Borowską-Stefańską (2012). Autorki nie generalizowały zapisów studiów gmin ŁOM.

Jeżeli teren był wielofunkcyjny, jak np. wspomniane wcześniej typy zespołów urbanistycznych $\mathrm{w}$ studium Wrocławia, przyporządkowano mu przeznaczenie podstawowe lub dominujące. Stosowano również funkcje mieszane. W opracowaniach planistycznych występuje pojęcie „terenu aktywności gospodarczej”, które dopuszcza realizację na danym obszarze (w zależności od ustaleń studium) przemysłu, baz, składów i ośrodków usługowych. Nie ma ono swojego odpowied- 
nika $\mathrm{w}$ rozporządzeniu $\mathrm{w}$ sprawie wymaganego zakresu projektu miejscowego planu zagospodarowania przestrzennego. Na potrzeby generalizacji przyjęto więc symbol U/P oznaczający tereny usługowo-produkcyjne. Dla obszarów zabudowy mieszkaniowo-usługowej wprowadzono skróty literowe MN/U i MW/U, które miały odróżnić zabudowę o funkcjach mieszanych od inwestycji planowanych tylko pod mieszkalnictwo (MN, MW).

W studiach gmin WrOM przewidziano ponadto następujące przeznaczenia: tereny nadrzeczne, łąki i pastwiska, zieleń nieurządzoną, obszary funkcjonalne przyrodniczo-krajobrazowe. W rozporządzeniu dotyczącym miejscowego planu zagospodarowania przestrzennego brak kategorii, w której zawierałyby się powyższe funkcje. Istnieje jednak grupa przeznaczeń oznaczona symbolem $\mathrm{ZN}$ zawierająca tereny zieleni objęte formami ochrony przyrody zgodnie z przepisami o ochronie przyrody, czyli parki narodowe, rezerwaty przyrody, parki krajobrazowe, obszary chronionego krajobrazu, obszary Natura 2000, pomniki przyrody, stanowiska dokumentacyjne, użytki ekologiczne, zespoły przyrodniczo-krajobrazowe, ochrona gatunkowa roślin, zwierząt i grzybów ${ }^{3}$. W niniejszej pracy do tej kategorii zakwalifikowano obszary związane z ogólnie pojętą zielenią nieurządzoną, nawet jeżeli nie były objęte prawną ochroną przyrody. Taką decyzję podjęto ze względu na rolę jaką pełnią tereny otwarte w systemie przyrodniczym WrOM. Kompleksy lasów, łąk, a także terenów podmokłych tworzą płaty, które jako obszary węzłowe zapewniają utrzymanie równowagi ekologicznej środowiska przyrodniczego oraz umożliwiają przetrwanie ekosystemów i gatunków (Warczewska, Mastalska-Cetera 2010: 161). Obszary te powinny być stosunkowo mało przekształcone na skutek działalności człowieka oraz charakteryzować się bogactwem gatunkowym i stabilnością funkcjonowania ekosystemów, występujących w ich obrębie (Szulczewska 2004: 56).

Pomimo ograniczonego zbioru przeznaczeń terenów, zawartego w rozporządzeniu w sprawie wymaganego zakresu projektu miejscowego planu zagospodarowania przestrzennego i znacznego zróżnicowania funkcji stosowanych w opracowaniach planistycznych, w kilku zaledwie przypadkach zaistniała konieczność przyjęcia własnych oznaczeń: dla opisanej powyżej zieleni nieurządzonej oraz linii i terenów kolejowych (TK), terenów zamkniętych, w tym poligonów wojskowych (TZ) oraz terenów lotnisk cywilnych (KL).

W postępowaniu badawczym przeprowadzonym przez J. Ulańską i M. Borowską-Stefańską (2012), kolejnym etapem było określenie zgodności albo niezgodności docelowego sposobu przeznaczenia terenu po obu stronach granicy gmin. Za niezgodność przyjęto każdą sytuację, kiedy sąsiadujące ze sobą sposoby przeznaczenia terenu były od siebie różne, nawet jeżeli nie były wobec siebie konfliktowe, np. las i tereny dolesień (Ulańska, Borowska 2012: 35).

3 Art. 6 ust. 1 Ustawy z dnia 16 kwietnia 2004 roku o ochronie przyrody (Dz.U. 2004, nr 92, poz. 880). 
W niniejszej pracy zaproponowano odmienne postępowanie badawcze w ramach tego etapu identyfikacji. Pierwsza różnica dotyczyła zakwalifikowania przeznaczeń do zgodnych i niezgodnych. Zagadnienie to przedstawiono w postaci graficznej za pomocą macierzy (tab. 1). Składa się ona z 625 pól odpowiadających poszczególnym wariantom, wynikającym z kompletu kombinacji 25 rodzajów przeznaczeń, do których sprowadzono występujące w studiach gmin WrOM funkcje terenów. W poszczególnych polach oznaczono, czy dana kombinacja oznacza zgodność czy niezgodność w przeznaczeniu czy też stanowi potencjalny konflikt przestrzenno-funkcjonalny. Stopień zgodności funkcji ustalono na podstawie literatury (Kołodziejski 1982; Grocholska 1983; Malisz 1984; Bański 1998; Dołzbłasz 2000; Szostek 2006; Mierzejewska 2009; Potocki, Szczęśniak 2009; Szczepańska 2009; Śleszyński, Solon 2010; Warczewska, Mastalska-Cetera 2010; Tokajuk 2011; Potocki, Piepiora 2013; Potocki i in. 2013) oraz doświadczenia zawodowego w zakresie planowania przestrzennego autorki pracy. Jeżeli w publikacjach nie zanotowano wzmianki ani opisu konfliktu w zakresie danych przeznaczeń, przyjęto, że są one zgodne. Jeżeli natomiast zestawienie funkcji wzmiankowane było w literaturze jako sytuacja konfliktowa i opisane w formie analizy pojedynczego przypadku, przypisywano mu niezgodność. Etykietę niezgodności nadawano również zestawieniu funkcji, z którymi autorka pracy spotkała się śledząc postępowania administracyjne, dotyczące uwag, odwołań i skarg wnoszonych w procesie uchwalania miejscowych planów i ustalania warunków zabudowy w decyzjach administracyjnych.

Kolejnym krokiem, różniącym metodologię autorstwa J. Ulańskiej i M. Borowskiej-Stefańskiej (2012), a postępowaniem badawczym zaproponowanym w niniejszej pracy, jest wytypowanie obszarów potencjalnie konfliktowych. Konflikty w ŁOM wskazane zostały przez analizę wszystkich niezgodności i wskazanie obszarów podlegających szczegółowej analizie. Polegała ona na przestudiowaniu miejscowych planów zagospodarowania, jeżeli takie dla tych obszarów są opracowane, następnie zdjęć lotniczych i map topograficznych, w celu wykluczenia obszarów, dla których konflikty są efektem zastałego zagospodarowania, którego zmiana w ramach prowadzonej polityki przestrzennej jest w znacznym stopniu ograniczona (Ulańska, Borowska-Stefańska 2012: 36). Mając na uwadze opracowanie metody identyfikacji potencjalnych konfliktów przestrzenno-funkcjonalnych możliwej do sprawnego i obiektywnego przeprowadzenia, jako działanie towarzyszące i uzupełniające konstruowanie opracowań z zakresu gospodarki przestrzennej, zaproponowano i wypróbowano inne rozwiązanie.

Potencjalne konfliktowe przeznaczenia terenów, oznaczone w macierzy cyfrą 2, wyznaczono na podstawie literatury przedmiotu. Pewne zestawienia funkcji opisywane są w wielu publikacjach (Kołodziejski 1982; Grocholska 1983; Malisz 1984; Bański 1998; Dołzbłasz 2000; Szostek 2006; Mierzejewska 2009; Potocki, Szczęśniak 2009; Szczepańska 2009; Śleszyński, Solon 2010; 
Tabela 1

Macierz zgodności przeznaczeń terenów występujących w studiach gmin WrOM

\begin{tabular}{|c|c|c|c|c|c|}
\hline 0 & $\begin{array}{c}\text { Zgodność } \\
\text { w przeznaczeniu terenów }\end{array}$ & 1 & $\begin{array}{c}\text { Niezgodność } \\
\text { w przeznaczeniu terenów }\end{array}$ & 2 & $\begin{array}{c}\text { Potencjalny konflikt } \\
\text { przestrzenno-funkcjonalny }\end{array}$ \\
\hline
\end{tabular}

\begin{tabular}{|c|c|c|c|c|c|c|c|c|c|c|c|c|c|c|c|c|c|c|c|c|c|c|c|c|c|}
\hline & $\mathbf{Z}_{\mathbf{z}}$ & $\sum$ & 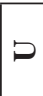 & $\mathscr{\Omega}$ & S & $\frac{\hat{s}}{2}$ & $\frac{2}{z}$ & $\frac{2}{3}$ & $\simeq$ & $\underset{\sim}{x}$ & $\sum_{\underline{x}}$ & 2 & ט & $\mathbf{Z}$ & $\vec{N}$ & $\hat{\mathbf{N}}$ & ลิ & $\mathbf{N}$ & $\begin{array}{l}\infty \\
3 \\
3\end{array}$ & 至 & $\mathscr{F}$ & $\underline{N}$ & 看 & 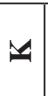 & 3 \\
\hline $\mathbf{Z}_{\mathbf{Z}}$ & 0 & 0 & 1 & 0 & 1 & 2 & 0 & 0 & 2 & 2 & 2 & 2 & 2 & 2 & 1 & 0 & 2 & 1 & 1 & 1 & 1 & 1 & 1 & 1 & \\
\hline$\sum$ & 0 & 0 & 1 & 0 & 1 & 2 & 0 & 0 & 2 & 2 & 2 & 2 & 2 & 2 & 1 & 0 & 2 & 1 & 1 & 1 & 1 & 1 & 1 & 1 & 2 \\
\hline$\triangleright$ & 1 & 1 & 0 & 1 & 0 & 0 & 1 & 1 & 1 & 1 & 1 & 0 & 0 & 2 & 1 & 1 & 1 & 1 & 1 & 0 & 0 & 1 & 0 & 1 & 2 \\
\hline ת & 0 & 0 & 1 & 0 & 1 & 2 & 0 & 0 & 2 & 2 & 2 & 2 & 2 & 1 & 2 & 0 & 2 & 1 & 0 & 1 & 0 & 1 & 1 & 1 & 1 \\
\hline ט & 1 & 1 & 0 & 1 & 0 & 0 & 1 & 1 & 1 & 1 & 1 & 0 & 1 & 2 & 1 & 1 & 1 & 1 & 1 & 0 & 0 & 1 & 0 & 1 & 2 \\
\hline$\hat{s}$ & 2 & 2 & 0 & 2 & 0 & 0 & 2 & 2 & 2 & 2 & 2 & 0 & 0 & 2 & 2 & 1 & 2 & 1 & 1 & 0 & 0 & 1 & 0 & 0 & \\
\hline$\sum_{\Sigma}^{2}$ & 0 & 0 & 1 & 0 & 1 & 2 & 1 & 1 & 2 & 2 & 2 & 2 & 1 & 2 & 1 & 1 & 1 & 1 & 1 & 1 & 1 & 1 & 1 & 1 & 2 \\
\hline$\sum_{\Sigma}^{R}$ & 0 & 0 & 1 & 0 & 1 & 2 & 2 & 2 & 2 & 2 & 2 & 2 & 1 & 2 & 1 & 1 & 1 & 1 & 1 & 1 & 1 & 1 & 1 & 1 & 2 \\
\hline$\simeq$ & 2 & 2 & 1 & 2 & 1 & 2 & 2 & 2 & 0 & 0 & 0 & 2 & 2 & 0 & 0 & 0 & 0 & 0 & 0 & 1 & 0 & 0 & 0 & 0 & 0 \\
\hline 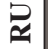 & 2 & 2 & 1 & 2 & 1 & 2 & 2 & 2 & 0 & 0 & 0 & 2 & 2 & 1 & 0 & 1 & 0 & 1 & 1 & 1 & 0 & 1 & 1 & 1 & 1 \\
\hline$\sum_{\Omega}$ & 2 & 2 & 1 & 2 & 1 & 2 & 2 & 2 & 0 & 0 & 0 & 2 & 2 & 1 & 0 & 0 & 0 & 1 & 1 & 1 & 0 & 1 & 1 & 1 & 1 \\
\hline 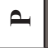 & 2 & 2 & 0 & 2 & 0 & 0 & 2 & 2 & 2 & 2 & 2 & 0 & 0 & 2 & 2 & 1 & 2 & 1 & 1 & 0 & 0 & 1 & 1 & 0 & \\
\hline Uּ & 2 & 2 & 0 & 2 & 1 & 0 & 2 & 2 & 2 & 2 & 2 & 0 & 0 & 1 & 2 & 1 & 2 & 1 & 1 & 0 & 0 & 1 & 1 & 1 & 1 \\
\hline $\mathbf{Z}$ & 2 & 2 & 2 & 1 & 2 & 2 & 2 & 2 & 0 & 1 & 1 & 2 & 1 & 0 & 0 & 0 & 0 & 0 & 0 & 1 & 1 & 0 & 1 & 1 & 0 \\
\hline $\overrightarrow{\mathbf{N}}$ & 1 & 1 & 1 & 1 & 1 & 1 & 1 & 1 & 0 & 0 & 0 & 2 & 2 & 0 & 0 & 0 & 0 & 0 & 0 & 1 & 0 & 0 & 1 & 1 & 0 \\
\hline$\hat{\mathbf{N}}$ & 0 & 0 & 1 & 0 & 1 & 1 & 0 & 0 & 0 & 1 & 0 & 1 & 1 & 0 & 0 & 0 & 0 & 0 & 0 & 1 & 0 & 1 & 0 & 0 & 0 \\
\hline ง & 2 & 2 & 1 & 2 & 1 & 2 & 2 & 2 & 0 & 0 & 0 & 2 & 2 & 0 & 0 & 0 & 0 & 0 & 0 & 1 & 0 & 1 & 0 & 0 & 1 \\
\hline $\mathbf{N}$ & 1 & 1 & 1 & 1 & 1 & 1 & 1 & 1 & 0 & 1 & 1 & 1 & 1 & 0 & 0 & 0 & 0 & 0 & 1 & 0 & 0 & 1 & 1 & 1 & 1 \\
\hline 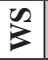 & 1 & 1 & 1 & 0 & 1 & 1 & 1 & 1 & 0 & 1 & 0 & 1 & 1 & 0 & 0 & 0 & 0 & 1 & 0 & 0 & 0 & 0 & 0 & 0 & 1 \\
\hline 童 & 1 & 1 & 0 & 1 & 0 & 0 & 1 & 1 & 1 & 1 & 1 & 0 & 0 & 1 & 1 & 1 & 1 & 0 & 0 & 0 & 0 & 0 & 0 & 0 & 1 \\
\hline$\stackrel{*}{*}$ & 1 & 1 & 0 & 0 & 0 & 0 & 1 & 1 & 0 & 0 & 0 & 0 & 0 & 1 & 0 & 0 & 0 & 0 & 0 & 0 & 0 & 0 & 0 & 0 & 1 \\
\hline $\mathbf{N}$ & 1 & 1 & 1 & 1 & 1 & 1 & 1 & 1 & 0 & 1 & 1 & 1 & 1 & 0 & 0 & 1 & 1 & 1 & 0 & 0 & 0 & 0 & 0 & 1 & 1 \\
\hline$\underline{z}$ & 1 & 1 & 0 & 1 & 0 & 0 & 1 & 1 & 0 & 1 & 1 & 1 & 1 & 1 & 1 & 0 & 0 & 1 & 0 & 0 & 0 & 0 & 0 & 0 & 1 \\
\hline 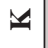 & 1 & 1 & 1 & 1 & 1 & 0 & 1 & 1 & 0 & 1 & 1 & 0 & 1 & 1 & 1 & 0 & 0 & 1 & 0 & 0 & 0 & 1 & 0 & 0 & 1 \\
\hline 3 & 2 & 2 & 2 & 1 & 2 & 2 & 2 & 2 & 1 & 1 & 1 & 2 & 1 & 0 & 0 & 0 & 1 & 1 & 1 & 1 & 1 & 1 & 1 & 1 & 0 \\
\hline
\end{tabular}


Objaśnienia zastosowanych w macierzy skrótów:

\begin{tabular}{|c|c|c|c|}
\hline MN & $\begin{array}{l}\text { - tereny zabudowy mieszkaniowej } \\
\text { jednorodzinnej }\end{array}$ & $\mathbf{P}$ & $\begin{array}{l}\text { - tereny obiektów produkcyjnych, } \\
\text { składów i magazynów }\end{array}$ \\
\hline MW & $\begin{array}{l}\text { - tereny zabudowy mieszkaniowej } \\
\text { wielorodzinnej }\end{array}$ & $\begin{array}{l}\text { PG } \\
\text { ZN }\end{array}$ & $\begin{array}{l}\text { - obszary i tereny górnicze } \\
\text { - tereny zieleni nieurzadzonej }\end{array}$ \\
\hline $\mathbf{U}$ & - tereny zabudowy usługowej & ZL & - lasy \\
\hline US & - tereny sportu i rekreacji & $\mathbf{Z P}$ & - tereny zieleni urzadzonej \\
\hline UC & $\begin{array}{l}\text { - tereny rozmieszczenia obiektów } \\
\text { handlowych o powierzchni } \\
\text { sprzedaży powyżej } 2000 \mathrm{~m}^{2}\end{array}$ & $\begin{array}{l}\mathrm{ZD} \\
\mathbf{Z C}\end{array}$ & $\begin{array}{l}\text { - tereny ogrodów działkowych } \\
\text { - cmentarze }\end{array}$ \\
\hline $\mathbf{U} / \mathbf{P}$ & $\begin{array}{l}\text { - tereny zabudowy usługowo- } \\
\text {-produkcyjnej }\end{array}$ & WS & $\begin{array}{l}\text { - tereny wód powierzchniowych } \\
\text { śródlądowych }\end{array}$ \\
\hline \multirow{2}{*}{\multicolumn{2}{|c|}{$\begin{array}{l}\text { MN/U, - tereny zabudowy mieszkaniowo- } \\
\text { MW/U - -usługowej }\end{array}$}} & KD & - tereny dróg \\
\hline & & TK & - linie i tereny kolejowe \\
\hline $\mathbf{R}$ & - tereny rolnicze & $\mathbf{T Z}$ & - tereny zamknięte \\
\hline RU & - tereny obsługi produkcji w gospo- & KL & - tereny lotnisk cywilnych \\
\hline & $\begin{array}{l}\text { darstwach rolnych, hodowlanych, } \\
\text { ogrodniczych oraz gospodar- }\end{array}$ & $\mathbf{K}$ & $\begin{array}{l}\text { - tereny infrastruktury technicznej } \\
\text { - kanalizacja }\end{array}$ \\
\hline & & $\mathbf{W}$ & - tereny infrastruktury technicznej \\
\hline $\mathbf{R M}$ & $\begin{array}{l}\text { - tereny zabudowy zagrodowej } \\
\text { w gospodarstwach rolnych, } \\
\text { hodowlanych i ogrodniczych }\end{array}$ & & \\
\hline
\end{tabular}

Źródło: opracowanie własne

Warczewska, Mastalska-Cetera 2010; Tokajuk 2011; Potocki, Piepiora 2013; Potocki i in. 2013) i zawsze określane jako konfliktowe. Jako potencjalne konflikty przestrzenno-funkcjonalne przyjęto sytuacje, gdy występują następujące kombinacje przeznaczeń: rolnictwo i leśnictwo a przemysł, rolnictwo i leśnictwo a turystyka i rekreacja, rolnictwo a mieszkalnictwo, mieszkalnictwo a przemysł, przemysł a rekreacja, przemysł, usługi uciążliwe i mieszkalnictwo a układy funkcjonalne ochrony zasobów środowiska przyrodniczego (ujęcia wody, parki krajobrazowe, rezerwaty przyrody).

W publikacjach, na podstawie których określono grupy konfliktowych funkcji, jako konflikt przestrzenny wskazuje się również transport w zestawieniu z mieszkalnictwem, sportem i rekreacją, rolnictwem oraz terenami cennymi przyrodniczo (por. Stasiak 1997; Badora 2004, 2005; Śleszyński, Solon 2010). W niniejszej pracy nie oznaczono jednak tych przeznaczeń jako konfliktowe, tylko jako niezgodne. Drogi są emitorami zanieczyszczeń, ale jednocześnie niezbędnym elementem zagospodarowania przestrzeni. Przy zastosowaniu proponowanej metody trudno ocenić wpływ komunikacji samochodowej na funkcjonowanie przylegających do niej terenów. W większości przypadków drogi mają swoje kontynuacje po drugiej 
stronie granicy jednostki terytorialnej, stąd podczas postępowania badawczego nie są wykazywane niezgodności. Wzdłuż autostrad, charakteryzujących się największą uciążliwością, koncentruje się działalność usługowa i produkcyjna.

Ostatnimi etapami postępowania badawczego są analiza i charakterystyka wyznaczonych konfliktów przestrzenno-funkcjonalnych oraz sformułowanie na ich podstawie wytycznych dla wladz samorządowych. Tak poprowadzone postępowanie umożliwi zaproponowanie sposobów likwidacji sytuacji konfliktowych (Ulańska, Borowska-Stefańska 2012: 36).

\section{Wyniki analizy}

W granicach obszaru badań analizie poddano przeznaczenie terenu występujące na 28 granicach gmin. Wyznaczono na nich 213 odcinków charakteryzujących się niezgodnym przeznaczeniem terenu występującym po obu stronach granicy, z czego 131 zakwalifikowano jako lokalizacje potencjalnych konfliktów przestrzenno-funkcjonalnych.

Nie objęto analizą oraz nie uwzględniono w zestawieniach liczbowych potencjalnych konfliktów przestrzennych zidentyfikowanych na dwóch stykach gmin: Czernica-Siechnice oraz Miękinia-Oborniki Śląskie. Granicę tych jednostek terytorialnych stanowi rzeka Odra, która na tych odcinkach ma szerokie koryto. W efekcie stanowi ona znaczącą barierę, oddzielającą obszary położonych wzdłuż niej gmin. Zdaniem autorki, w takich warunkach funkcje zlokalizowane po obu stronach rzeki, nawet jeżeli są konfliktowe, nie mają na siebie bezpośredniego wpływu.

Z powodu złej jakości oraz dużych niedokładności części załączników graficznych studium uwarunkowań i kierunków zagospodarowania przestrzennego, stanowiących źródło danych dla badań, nie było możliwe obliczenie długości granic, na których występują potencjalne konflikty przestrzenno-funkcjonalne.

Przeprowadzone badania wskazują na istnienie pewnych zależności przestrzennych w występowaniu potencjalnych konfliktów. Największym ich udziałem cechuje się Wrocław oraz gminy strefy podmiejskiej. Wrocław jako miasto centralne oraz tereny położone $\mathrm{w}$ jego najbliższym sąsiedztwie, charakteryzują się silnym natężeniem procesów urbanizacyjnych, stąd duże zróżnicowanie przeznaczeń terenów na stykach gmin. W miarę oddalania się od rdzenia obszaru metropolitalnego, zmniejsza się dynamika procesów inwestycyjnych i zwiększa udział terenów otwartych, mniej lub bardziej skutecznie, ale jednak podlegających ochronie.

Wrocław graniczy z ośmioma gminami. Potencjalnych konfliktów przestrzennych nie wykazano tylko na jednym ze styków - z gminą Oborniki Śląskie. Na pozostałych granicach liczba potencjalnych sytuacji konfliktowych waha się od 2 do 15 , przy czym wartość 15 można uznać za wysoki wynik na tle całego obszaru 
metropolitalnego (ryc. 2). Gminy charakteryzujące się również dużym udziałem konfliktów przestrzennych na odcinkach nie będących granicami z Wrocławiem to Kobierzyce-Żórawina oraz miasto i gm. Oleśnica. Powodem może być bardzo duża intensywność procesów inwestycyjnych na obszarze Kobierzyc i Żórawiny - dotyczy to zarówno budownictwa mieszkaniowego, jak i inwestycji produkcyjnych. W tym kontekście również wysoką konfliktowość na stykach miasta i gminy Oleśnica można wytłumaczyć wielofunkcyjnością tego ośrodka miejskiego, otoczonego przez gminne obszary użytków rolniczych oraz zabudowy mieszkaniowej i zagrodowej. Poza miastem Wrocław jednostką, która cechuje się występowaniem potencjalnych konfliktów przestrzennych na wszystkich swoich granicach w dużym natężeniu jest gm. Wisznia Mała, charakteryzująca się zjawiskami urbanizacyjnymi, typowymi dla strefy podmiejskiej.

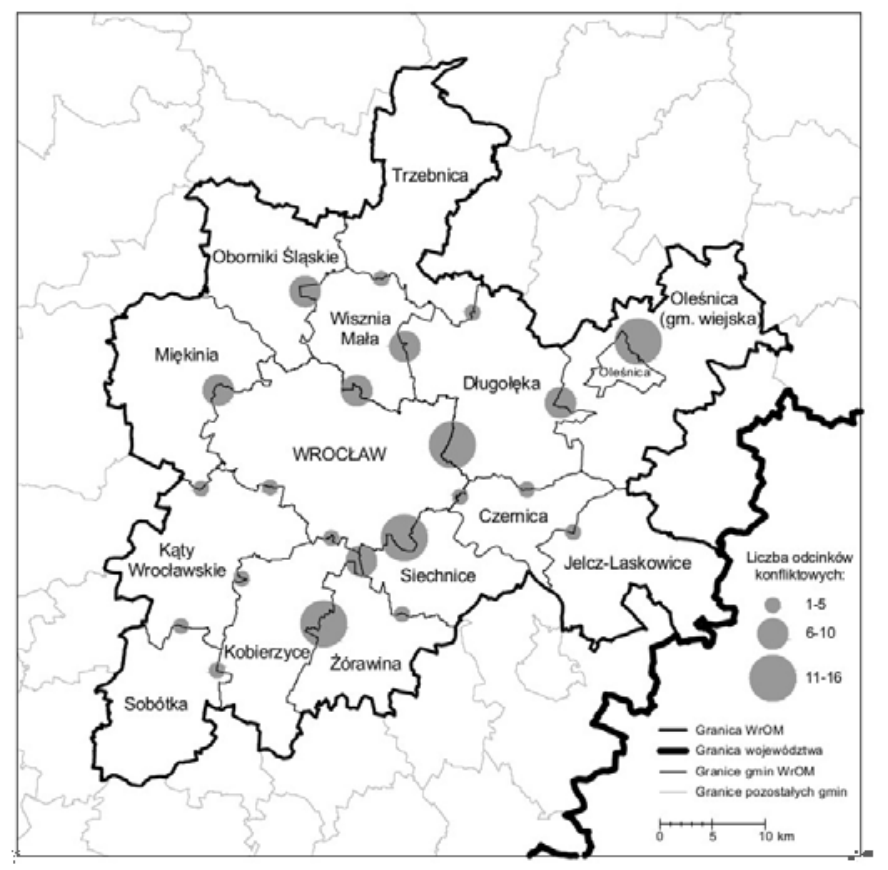

Ryc. 2. Liczba odcinków konfliktowych na stykach gmin we WrOM - stan w 2016 roku Źródło: opracowanie własne

\section{Podsumowanie}

Przyjęta w pracy metoda umożliwiła identyfikację 19 rodzajów potencjalnych konfliktów przestrzenno-funkcjonalnych na obszarze WrOM. Spośród nich najwięcej związanych jest z sąsiedztwem terenów zabudowy mieszkaniowej i mieszkaniowo-usługowej z terenami użytkowanymi rolniczo i innymi terenami otwartymi 
(tereny nadrzeczne, łąki i pastwiska, zieleń nieurządzoną, obszary funkcjonalne przyrodniczo-krajobrazowe). Stanowią one odpowiednio 38\% i 13\% liczby wszystkich zidentyfikowanych sytuacji konfliktowych na obszarze objętym badaniem. Kolejną kombinacją przeznaczeń o potencjalnie konfliktowym charakterze jest zabudowa mieszkaniowa i mieszkaniowo-usługowa $\mathrm{z}$ terenami usługowo-produkcyjnymi - 13\% zidentyfikowanych konfliktów przestrzennych. Zbliżoną wartość osiągnęło kolizyjne zestawienie zabudowy usługowo-produkcyjnej z terenami użytkowanymi rolniczo - $12 \%$.

W zaproponowanej w artykule metodologii starano się zautomatyzować postępowanie badawcze, poprzez wypracowanie wzorów, na podstawie których podejmowane byłyby decyzje dotyczące stopnia zgodności przeznaczeń terenów. Opracowanie takich schematów sprawi, że identyfikacja konfliktów będzie możliwa do realizacji powszechnie, jako element towarzyszący i uzupełniający działania decyzyjne $\mathrm{w}$ zakresie planowania przestrzennego. Usprawni to pracę oraz poprzez wprowadzenie jasnych kryteriów zminimalizuje subiektywizm, którym obciążone jest wyznaczanie potencjalnych sytuacji konfliktowych. Kombinacje przeznaczeń uznanych za konfliktowe, nie ujęte w opracowanych wzorach, można uznać za przypadki jednostkowe. Stosując takie podejście możliwe będzie skoncentrowanie się na zjawiskach mających rzeczywiste, ze względu na częstotliwość i zasięg terytorialny, przełożenie na gospodarowanie przestrzenią.

Ze względu na złożoność zjawiska nie można stwierdzić z całą pewnością, że przeznaczenia zakwalifikowane jako zgodne nie okażą się konfliktowymi i odwrotnie - funkcje potencjalnie niezgodne mogą egzystować nie wpływając na siebie negatywnie. Zaproponowane podejście badawcze zapewni jednak większą kontrolę w przeznaczaniu terenów pod nowe funkcje i umożliwi eliminowanie potencjalnych konfliktów przestrzenno-funkcjonalnych już na etapie planowania.

Brak ujednoliconych zapisów w opracowaniach planistycznych, w tym studiach uwarunkowań i kierunków zagospodarowania przestrzennego, znacząco utrudnia porównywanie dokumentów sąsiadujących ze sobą gmin. W skali kraju takie porównania wydają się natomiast niemożliwe do zrealizowania. Zaproponowana generalizacja zapisów przeznaczeń terenów, sprowadzająca określenia zastosowane w opracowaniach do nomenklatury zawartej w rozporządzeniu w sprawie wymaganego zakresu projektu miejscowego planu zagospodarowania przestrzennego, byłaby rozwiązaniem tego problemu. Standaryzacja zapisów dokumentów planistycznych umożliwi porównywalność w skali kraju niezależnie od zmiennych zapisów studiów.

\section{LITERATURA}

Aspinall R. (red.), 2006, „Journal of Land Use Science”, 1: 1-4.

Badora K., 2004, Autostrada - środowisko przyrodnicze - studium konfliktów przestrzennych na przyktadzie opolskiego odcinka autostrady A-4, „Studia i Monografie Uniwersytetu Opolskiego", 349. 
Badora K., 2005, Konflikty przestrzenne na styku autostrada-ochrona przyrody na przykładzie opolskiego odcinka autostrady A-4, „Przegląd Przyrodniczy”, 14(3-4): 109-119.

Bański J., 1998, Gospodarka ziemia w Polsce w okresie restrukturyzacji, IGiPZ PAN, Warszawa.

Bański J., 1999, Obszary problemowe w rolnictwie Polski, „Prace Geograficzne”, 172.

Białyszewski H., 1983, Teoretyczne problemy sprzeczności i konfliktów społecznych, PWN, Warszawa.

Deutsch M., 1973, Conflicts: Productive and destructive, [w:] Jandt F.E. (red.), Conflict resolution through communication, Harper \& Row, New York: 155-197.

Dmochowska-Dudek K., 2011, Obiekty NIMBY jako przykład konfliktowych inwestycji na terenach mieszkaniowych - teoretyczny zarys problemu, „Space-Society-Economy”, 10: 29-56.

Dołzbłasz S., 2000, Konflikty przestrzenne w zagospodarowaniu strefy podmiejskiej Wroctawia, [w:] Ciok S., Ilnicki D. (red.), Przeksztatcenia regionalnych struktur funkcjonalno-przestrzennych, 5, Wrocław: 91-101.

Domański R., 1991, Cele wielorakie i konflikty w gospodarce przestrzennej, „Biuletyn KPZK PAN", 155, Warszawa: 89-129.

Dutkowski M.,1996, Konflikty środowiskowe w ujęciu wielodyscyplinarnym, [w:] Domański R. (red.), Nowa generacja w badaniach gospodarki przestrzennej, „Biuletyn KPZK PAN", 174, Warszawa: 29-47.

Dziewoński K., 1974, Badania geograficzne dla potrzeb planowania przestrzennego 1944-1974, „Przegląd Geograficzny”, 46(4), Warszawa: 577-596.

Fraser N.M., Hipel K.W., 1984, Conflict analysis: Models and Resolutions, North Holland, New York.

Furmankiewicz M., Potocki J., 2004, Przyroda a gospodarka - konflikty ekologiczne w zagospodarowaniu przestrzennym Sudetów, [w:] Problemy ochrony przyrody w zagospodarowaniu przestrzennym Sudetów, Muzeum Przyrodnicze w Jeleniej Górze: 7-20.

Gołąb-Korzeniowska M., 2008, Konflikty środowiskowe w rozwoju struktury przestrzennej regionu metropolitalnego, „Czasopismo Techniczne”, 5A, Kraków: 61-73.

Gonda-Soroczyńska E., 2009, Przemiany strefy podmiejskiej Wrocławia w ostatnim dziesięcioleciu, „Infrastruktura i Ekologia Terenów Wiejskich”, 4, Polska Akademia Nauk Oddział w Krakowie: 149-165.

Grocholska J., 1979, Problematyka obszarów konfliktowych w planowaniu przestrzennym, [w:] Malisz B. (red.), Metody analiz geograficznych $w$ planowaniu przestrzennym, „Dokumentacja Geograficzna IGiPZ PAN”, 3: 84-93.

Grocholska J., 1980, Obszary konfliktowe - problem badawczy w przestrzennym zagospodarowaniu kraju, „Przegląd Geograficzny”, 52 (3), Warszawa: 507-517.

Grocholska J., 1983, Problematyka obszarów konfliktowych. Podejście teoretyczne z przykładami, [w:] Kukliński A. (red.), Problemy rekonstrukcji metodologicznej polskich studiów regionalnych, „Biuletyn KPZK PAN”, 124, Warszawa: 117-133.

Grocholska J., 1986, Konflikty w planowaniu przestrzennym i próby ich rozwiązania (na przykładzie wybranych obszarów aglomeracji warszawskiej). Studia nad funkcjonalnym makroregionem Warszawy (III), „Biuletyn Informacyjny”, 53, IGiPZ PAN: 205-222.

Grochowska A., 2014, Istniejace $i$ potencjalne konflikty przestrzenne $w$ parkach krajobrazowych, [w:] Ciok S., Janc K. (red.), Współczesne wyzwania polityki regionalnej 
i gospodarki przestrzennej, t. 2, „Rozprawy Naukowe Instytutu Geografii i Rozwoju Regionalnego", 33 (2), Uniwersytet Wrocławski, Wrocław: 161-171.

Grochowska A., 2015, Zagrożenia i konflikty w zakresie zagospodarowania przestrzennego na terenie Parku Krajobrazowego Sudetów Wałbrzyskich, [w:] Brol R., Raszkowski A., Sztando A. (red.), Gospodarka lokalna w teorii i praktyce, „Prace Naukowe Uniwersytetu Ekonomicznego we Wrocławiu", 391, Wrocław: 147-155.

Grochowska A., 2016, Konflikty przestrzenne w planowaniu przestrzennym obszarów metropolitalnych na przykładzie Wrocławskiego Obszaru Metropolitalnego, „Rozprawy Naukowe Instytutu Geografii i Rozwoju Regionalnego”, 38, Uniwersytet Wrocławski, Wrocław.

Hełdak M., 2012, Decyzje planistyczne a przemiany krajobrazu kulturowego obszarów wiejskich, Wrocław.

Jabłoński W., Mazurkiewicz K., 2014, Konflikty przestrzenne na terenach wiejskich - ignorancja czy niewiedza? Studium przypadku, „Infrastruktura i Ekologia Terenów Wiejskich", 2014/IV, Kraków: 1167-1177.

Jones C., Baker M., Carter J., Jay S., Short M., Wood C., 2005, Strategic environmental assessment and land use planning. An international evaluation, Earthscan, London: 1-3.

Kistowski M., 2008, Problemy lokalizowania inwestycji na terenach cennych przyrodniczo, [w:] Gwiazdowicz M. (red.), Ochrona przyrody, „Studia Biura Analiz Sejmowych Kancelarii Sejmu", 10, Wydawnictwo Sejmowe Kancelarii Sejmu, Warszawa: 139-163.

Kołodziejski J., 1982a, Realizacja celów rozwoju w warunkach narastania konfliktów w gospodarce przestrzennej, [w:] Konflikty polskiej przestrzeni, „Biuletyn KPZK PAN”, 120: $27-51$.

Kołodziejski J., 1982b, Geneza, funkcjonowanie oraz ocena sytuacji konfliktowych w gospodarce przestrzennej Polski, [w:] Diagnoza stanu gospodarki przestrzennej Polski: wstępne wyniki badań, „Biuletyn KPZK PAN”, 123: 134-148.

Kołodziejski J., 1988, Uwarunkowania przestrzenne ochrony środowiska przyrodniczego, [w:] Planowanie przestrzenne jako narzędzie ochrony środowiska przyrodniczego, „Biuletyn KPZK PAN”, 139: 8-73.

Kołodziejski J., 1991, O przyszły kształt polskiej przestrzeni, Wszechnica PAN, Wydawnictwo PAN, Zakład Narodowy im. Ossolińskich.

Krajewska H., 2004, Konflikt w gospodarce przestrzennej, [w:] Markowski T. (red.), Przestrzeń w zarzadzaniu rozwojem regionalnym i lokalnym, „Biuletyn KPZK PAN”, Warszawa: 337-354.

Lendzion J., 1987, Gra jako model konfliktu środowiskowego w przestrzeni, „Zeszyty Naukowe Politechniki Śląskiej. Seria Architektura", 4: 149-154.

Malisz B., 1977, Rola badań geograficznych w planowaniu przestrzennym, „Przegląd Geograficzny", 49 (2), Warszawa: 319-331.

Malisz B., 1984, Podstawy gospodarki i polityki przestrzennej, Wszechnica PAN, Wydawnictwo PAN, Zakład Narodowy im. Ossolińskich.

Markowski T., 1999, Zarządzanie rozwojem miast, Wydawnictwo Naukowe PWN, Warszawa.

Mierzejewska L., 2009, Rozwój zrównoważony miasta. Zagadnienia poznawcze i praktyczne, Wydawnictwo Naukowe UAM, Poznań.

Niewiadomski Z. (red.), 2006, Planowanie i zagospodarowanie przestrzenne. Komentarz, Warszawa. 
Potocki J., Szczęśniak E., 2009, Rozwój przestrzenny wałbrzyskiego zespołu miejskiego i jego wpływ na przemiany systemu przyrodniczego, [w:] Markowski T., Drzazga D. (red.), System przyrodniczy w zarządzaniu rozwojem obszarów metropolitalnych, „Studia KPZK PAN", 123, Warszawa: 162-171.

Potocki J., Piepiora Z., 2013, Antropogeniczne uwarunkowania powodzi błyskawicznych na terenach górskich - przykład Maciejowej, [w:] Kościk E. (red.), Gdy nadciagała wielka woda. Klęski powodzi na ziemiach polskich na przestrzeni wieków, Wrocławskie Spotkania z Historią Gospodarczą, vol. Spotkanie 8, Wydawnictwo GAJT, Wroclaw: 127-134.

Potocki J., Kachniarz M., Szutka K., Ziablicki T., 2013, Przemiany struktury przestrzennej i dylematy rozwojowe Karpacza jako miasta turystycznego, „Acta Universitatis Lodziensis. Folia Geographica Oeconomica", 15: 139-150.

Rozporzadzenie Ministra Infrastruktury z dnia 26 sierpnia 2003 roku w sprawie wymaganego zakresu projektu miejscowego planu zagospodarowania przestrzennego (Dz.U. 2003, nr 164, poz. 1587).

Schelzig K., 2005, Poverty in the Philippines: Income, Assets, and Access, Asian Develoment Bank (ADB).

Stasiak A. (red.), 1997, Konflikty wokół autostrad w Polsce, KPZK PAN, Warszawa.

Szczepańska A., 2009, Procesy decyzyjne w gospodarce przestrzennej, „Space-Society-Economy", 9: 43-51.

Szostek W., 2006, Konflikty w procesie realizacji polityki przestrzennej, [w:] Ossowicz T., Zipser T. (red.), Urbanistyka $w$ działaniu. Teoria i praktyka, II Kongres Urbanistyki Polskiej, Wrocław.

Szulczewska B., 2004, Planowanie przestrzenne jako instrument realizacji sieci ekologicznych - między teoria a praktyka, [w:] Platy i korytarze jako elementy struktury krajobrazu - możliwości i ograniczenia koncepcji, „Problemy Ekologii Krajobrazu”, 14, Wydawnictwo SGGW, Warszawa: 54-62.

Śleszyński P., 2004, Kształtowanie się zachodniej części centrum Warszawy, „Prace Geograficzne", 196, IGiPZ PAN, Warszawa.

Śleszyński P., Solon J. (red.), 2010, Prace planistyczne a konflikty przestrzenne w gminach, „Studia KPZK PAN”, 130, Warszawa.

Tokajuk J., 2011, Konflikty przestrzenne na styku istniejacej zabudowy zagrodowej i planowanej zabudowy mieszkaniowej na terenach wsi strefy podmiejskiej właczonych do obszaru miasta Białegostoku, „Przestrzeń i Forma”, 15, Szczecin: 311-320.

Ulańska J., Borowska-Stefańska M., 2012, Użytkowanie ziemi i polityka przestrzenna w Eódzkim Obszarze Metropolitalnym, [w:] Bartosiewicz B., Marszał T., Pielesiak I. (red.), Spójność terytorialna Łódzkiego Obszaru Metropolitalnego, „Studia KPZK PAN", 147, Warszawa: 14-43.

Ustawa z dnia 16 kwietnia 2004 roku o ochronie przyrody (Dz.U. 2004, nr 92, poz. 880).

Ustawa z dnia 27 marca 2003 roku o planowaniu $i$ zagospodarowaniu przestrzennym (Dz.U. 2003, nr 80, poz. 717).

Warczewska B., Mastalska-Cetera B., 2010, Charakterystyka Wrocławskiego Obszaru Metropolitalnego ze szczególnym uwzględnieniem systemu przyrodniczego, „Acta Universitatis Lodziensis. Folia Oeconomica”, 245, Wydawnictwo Uniwersytetu Łódzkiego: 157-167. 
Zatorska-Sadurska J., 1990, Koncepcja kompleksowej waloryzacji środowiska jako podstawa identyfikacji sytuacji konfliktowych $w$ zagospodarowaniu przestrzennym, Politechnika Gdańska, 9, Gdańsk: 43-84.

Zuziak Z.K., 1995, Rozwiazywanie konfliktów środowiskowych w gospodarce przestrzennej, [w:] Salomon L.M. i in. (red.), Gospodarka samorzadów terytorialnych w świetle doświadczeń amerykańskich, Fundacja Promocji Czystych Technologii TECHEKO, Łódź: 138-167.

Źróbek S., Zachaś M., 2003, Identyfikacja konfliktów przestrzennych na poziomie lokalnym $w$ procesie sporzadzania miejscowego planu zagospodarowania przestrzennego, „Acta Scientiarum Polonorum. Administratio Locorum”, 2(1-2), Wydawnictwo Uniwersytetu Warmińsko-Mazurskiego w Olsztynie, Olsztyn: 5-19.

\title{
INCOMPATIBILITY OF FORM OF PLACEMENT IN SPATIAL PLANTS - METHOD OF IDENTIFICATION OF POTENTIAL SPATIAL AND FUNCTIONAL CONFLICTS
}

\begin{abstract}
This article deals with the subject of spatial conflicts in metropolitan areas. It examines potential conflicts which are understood as a set of spatial and functional phenomena resulting from spatial planning policies carried out by local governments.

The main aim of the research conducted as part of this article was to identify potential conflicts in spatial planning. The practical goal of this paper is to propose a method of identifying spatial conflicts and make recommendations for landscape policies and draw up planning studies on the local level. The choice of methodology was based on the assumption that spatial conflicts occur predominantly on the borders between various communes. The main research material were analyses of conditions and trends in spatial development planning.
\end{abstract}

Keywords Spatial conflicts, land use conflicts, spatial planning policies, metropolitan areas.

Dr Anna Grochowska Zakład Zagospodarowania Przestrzennego Wydział Nauk o Ziemi i Kształtowania Środowiska Uniwersytet Wrocławski e-mail: anna.grochowska@uwr.edu.pl 